\title{
Seasonal Drought Effects on Intra-Annual Stem Growth of Taiwan Pine along an Elevational Gradient in Subtropical China
}

\author{
Xinsheng Liu ${ }^{1,2, * \mathbb{C}}$, Chunsong Wang ${ }^{1}$ and Junkai Zhao ${ }^{1}$ \\ 1 College of Tourism and Geography, Jiujiang University, East Qianjin Road No. 551, Jiujiang 332005, China; \\ wcs3458719645@163.com (C.W.); junkaizhao@163.com (J.Z.) \\ 2 DendroLab, Department of Natural Resources and Environmental Science, University of Nevada, Reno, \\ NV 89557, USA \\ * Correspondence: xsliu287@gmail.com
}

Received: 17 November 2019; Accepted: 9 December 2019; Published: 10 December 2019

\begin{abstract}
Knowledge of intra-annual stem growth dynamics across environmental gradients is important for advancing our ability to understand the adaptability and vulnerability of subtropical tree species to future climate change. To assess the effects of seasonal drought on intra-annual stem growth, stem radial variation of Taiwan pine (Pinus taiwanensis Hayata) was monitored with band dendrometers for two years along an elevation transect from 921 to $1402 \mathrm{~m}$ in the Lushan Mountains, a transect that covers the contrasting climatic growing conditions for Taiwan pine in southeastern China. We found that the onset of stem growth was nearly synchronous across the transect, in early April 2017 and in late March 2018, whereas large elevational differences were observed for the end of the growing season, which was much earlier at lower elevations. Tree stems frequently rehydrated during the dry growing seasons at the two higher elevations, suggesting that seasonal drought had minor influence on the offset of high-elevation stem growth. A substantial and continuous tree water deficit of low-elevation Taiwan pine was detected during dry seasons, leading to an early growth cessation in late July in both years. Tree water status (reflected by tree water deficit) revealed a higher sensitivity to precipitation and soil water content across wet- and dry-seasons at the lowest elevation than at high elevations, indicating that low-elevation stem radial growth was highly dependent on moisture variables over the whole growing season. Due to the influences of seasonal drought on growth cessation and rates, Taiwan pine produced a rather narrow annual growth at the lowest site, whereas high-elevation Taiwan pine could benefit from the optimal wet-season environmental conditions and the reactivation of cambial activity during dry seasons. Our findings suggest that the more frequent and intensive drought episodes in the future will reduce tree growth of Taiwan pine at the dry edge, probably resulting in upward shifting of the optimal elevation for Taiwan pine in subtropical China.
\end{abstract}

Keywords: elevational gradient; seasonal drought; tree growth; tree water deficit; Pinus taiwanensis Hayata; subtropical forest

\section{Introduction}

Climate change has led to temperature increase and more frequent and severe drought events, which is expected to pose major challenges for forest growth, plant species composition and ecosystem services [1]. In the past decades, a continued warming with changes in precipitation seasonality (i.e., more rain-free days and droughts in dry season and frequent floods in wet season) was observed in subtropical China [2]. To better understand how tree growth is responding to changing environmental 
conditions, it is crucial to examine the climatic forcing of tree growth at short- and long-term scales. However, many previous tree-ring-based investigations of conifers have demonstrated complicated growth-climate relationships in subtropical forests, varying from a positive correlation with winter half-year temperature [3-8] to a positive response to summer-season precipitation [9-12]. Such contradictions limit our ability to predict how subtropical tree growth responds to future climate changes. Hence, in-depth investigations on the intra-annual stem growth dynamics and its physiological basis are urgently needed.

Seasonal stem growth dynamics have been intensively monitored in boreal and temperate forests using dendrometers and quantitative wood anatomy (e.g., micro-coring) [13-18]. While wood anatomical methods allow for an accurate description of wood formation at the cellular level through weekly sampling micro-cores, dendrometer-based stem radial variation can provide detail tree physiological reactions at higher temporal resolutions (sub-hourly and daily) without wounding the cambium. Importantly, dendrometer-derived diurnal stem radial variations consist not only of irreversible radial growth of new xylem cells but also of reversible stem shrinking and swelling (reflecting water storage dynamics in tree stems), thereby providing continuous information on tree water status and further facilitating the physiological interpretation of stem growth under drought stress $[14,15,19,20]$. Despite this, intra-annual stem growth dynamics and its response to regional climate are still very scarce in subtropical China, among which most studies focused on a single site with limited observation years [21-23]. On the other hand, it has been documented that studying seasonal stem growth dynamics over an elevational gradient, in which warm and dry conditions at the lower elevation served as a natural analog to simulate future climate, could shed more light on the mechanisms of tree growth under future climate change scenarios [24,25].

Across biomes, several studies have reported divergent elevational variations of intra-annual stem growth for the same tree species. In general, the initiation of stem growth was linearly delayed with increasing elevations in cold-limited forests, which was primarily driven by temperature variability along elevational gradients [24,26-28]. There was also a non-distinct elevational pattern for initiation of stem growth in water-limited forests $[25,29]$, suggesting that growth resumption may both determined by temperature and/or precipitation [30,31]. In contrast, there is little clarity or consensus regarding the elevational pattern in cessation of stem growth. Photoperiod predominately controlled the ending of tree growth and a resultant uniform ending of wood formation among different elevations was observed in cold-limited forests $[24,27,28]$, while water shortage mainly played an important role in determining the offset of stem growth in arid and semi-arid regions $[25,29]$ and even at the drought-prone lower edge in temperate forests [26,32]. However, although much uncertainty still remains with regard to the elevational pattern of intra-annual stem growth, how seasonal tree growth is controlled by prevailing climatic conditions at different elevations has rarely been explored in subtropical China.

Pinus taiwanensis Hayata (Taiwan pine), a most important foundation conifer tree species in southeastern China, is distributed over a wide range of elevations between 800 to $1700 \mathrm{~m}$. This conifer is moderately cold-tolerant and well adapted to cool and wet habitats in mountainous areas, thus, providing crucial ecological values in soil and water conservation and biodiversity for regional ecosystems [33]. Our preliminary studies indicated that intra-annual stem growth of high-elevation Taiwan pine trees was constrained by seasonal drought, and growth-limiting factors shifted seasonally from temperatures in spring and early summer to water availability in summer and autumn [21]. Given a high sensitivity to water stress, the ongoing increase in seasonal drought intensity and severity is expected to reduce tree growth and suitable habitats for Taiwan pine, especially at the lower edges. Nevertheless, the seasonal drought effects on intra-annual stem growth of Taiwan pine at different elevations in subtropical forests remain largely unclear. It is, therefore, critical to clarify these issues through an investigation of intra-annual stem growth along an elevational gradient, which is particularly relevant to predict the response of Taiwan pine in the context of climate change.

We measured stem radial variations of Taiwan pine at three sites along an elevational transect over a two-year period (2017-2018) in the Lushan Mountains, southeastern China. The specific goals 
of this study were to (i) compare the intra-annual stem growth dynamics (i.e., growth initiation, peak and cessation, and growth rates) among different elevations and (ii) determine to what extent the elevational and inter-annual variations in stem radial growth are related to seasonal drought. We expected to find distinct differences among elevations in dynamics of intra-annual stem growth and tree water deficit as well as stem radial growth because of the increased intensity of seasonal drought towards lower elevations.

\section{Material and Methods}

\subsection{Study Area and Tree Selection}

The study area was located on a west-facing slope at the Lushan Mountains $\left(29^{\circ} 33^{\prime} \mathrm{N}, 115^{\circ} 58^{\prime}\right.$ E, 921-1402 $\mathrm{m}$ a.s.1.), $25 \mathrm{~km}$ south of Jiujiang city, in southeastern China. Thanks to the preservation since 1970s, the forest stands in Lushan Mountains were established from natural regeneration [33]. Taiwan pine (Pinus taiwanensis Hayata) is the dominant canopy vegetation between $800 \mathrm{~m}$ and $1474 \mathrm{~m}$, which mainly forms pure stands above $1000 \mathrm{~m}$ and co-occurs with broad-leaved tree species at 800-1000 $\mathrm{m}$ in Lushan Mountains [33]. The climate is typically subtropical monsoon, characterized by an alternation from wet season (March-June) to dry season (July-November). The mean annual temperature and precipitation are $11.9^{\circ} \mathrm{C}$ and $2009 \mathrm{~mm}$, respectively (1980-2011, meteorological station at Lushan Mountain, $1165 \mathrm{~m}$ a.s.1.) [21]. We selected three forest plots located at elevations between 921 and $1402 \mathrm{~m}$, coving an elevation range of circa $500 \mathrm{~m}$ for Taiwan pine (Table 1). Although Taiwan pine formed pure stands at the two higher sites, mixed stands composed of Taiwan pine, Japanese cypress (Chamaecyparis obtuse), Japanese cedar (Cryptomeria japonica), and Konara oak (Quercus serrata) are developed at the lowest site. At each site, three or five upright and healthy Taiwan pine trees with similar dominance and well-developed crowns were selected to monitor stem radial variations. To minimize the age effects on radial growth and tree water deficit, selected trees had an average tree age of $33 \pm 5$ years, diameter at breast height $(\mathrm{DBH})$ of $19.7 \pm 3.5 \mathrm{~cm}$, and height of $6.5 \pm 1.1 \mathrm{~m}$ (Table 1). There were no significant differences in tree age, DBH and height among elevations.

Table 1. Geographic coordinates of the forest stands and diameter at breast height (DBH), age, and height of selected trees at the three sites along the elevation gradient. Mean values \pm standard deviations (SD) are shown.

\begin{tabular}{ccccccc}
\hline $\begin{array}{c}\text { Elevations } \\
(\mathbf{m})\end{array}$ & Latitude & Longitude & $\begin{array}{c}\text { Number of } \\
\text { Trees }(\boldsymbol{n})\end{array}$ & DBH (cm) & Age (year) & Height (m) \\
\hline 921 & $29^{\circ} 33^{\prime} 26^{\prime \prime}$ & $115^{\circ} 57^{\prime} 53^{\prime \prime}$ & 3 & $19.3 \pm 1.8$ & $32 \pm 3$ & $7.7 \pm 0.9$ \\
1170 & $29^{\circ} 33^{\prime} 36^{\prime \prime}$ & $115^{\circ} 58^{\prime} 39^{\prime \prime}$ & 5 & $19.7 \pm 5.1$ & $33 \pm 8$ & $5.9 \pm 0.4$ \\
1402 & $29^{\circ} 33^{\prime} 40^{\prime \prime}$ & $115^{\circ} 59^{\prime} 15^{\prime \prime}$ & 3 & $20.1 \pm 2.4$ & $33 \pm 4$ & $5.9 \pm 0.8$ \\
\hline
\end{tabular}

\subsection{Measurements of Stem Radial Variation}

Stem radial variation at breast height (1.3 $\mathrm{m}$ above ground) was continuously monitored using automatic band-type dendrometers (DRL26C, EMS, Brno, Czech Republic) with an accuracy of $1 \mu \mathrm{m}$ at three or five individual Taiwan pine trees per site. To avoid the effects of bark shrinking and swelling on dendrometer records, we carefully peeled off the dead tissues of the bark before installation $[13,18]$. The band dendrometer equips with a rotary position sensor, which measures the circumference of the stainless tape pressed against tree stems. All data were recorded at hourly interval with a built-in data logger (DRL26C, EMS, Brno, Czech Republic), and were further transformed to stem radius assuming a circular cross-section of sampled trees. Due to that the beginning of data acquisition differed among the three sites, the subsequent analysis of stem radial variation was limited to 2017 and 2018. 


\subsection{Microclimate Measurements}

At each forest plot along the elevation gradient, a weather station (HOBO U30, Onset, Bourne, MA, USA) was placed to monitor microclimate conditions within a 20-m distance of the sampled trees. Air temperature $\left(\mathrm{T}_{\mathrm{a}},{ }^{\circ} \mathrm{C}\right)$, relative humidity $(\mathrm{RH}, \%)$, precipitation $(\mathrm{Pr}, \mathrm{mm})$ were recorded at the top of a 3-m tower, while soil temperature $\left(\mathrm{T}_{\mathrm{s}},{ }^{\circ} \mathrm{C}\right)$ and volumetric soil water content $\left(\mathrm{SWC}, \mathrm{m}^{3} \mathrm{~m}^{-3}\right.$ ) were measured at $10 \mathrm{~cm}$ soil depth. Recording interval was set to $30 \mathrm{~min}$ and stored in data loggers (U30-NRC, Onset, Bourne, MA, USA) since January 2017. Vapor pressure deficit (VPD) was calculated by using half-hour values of air temperature and relative humidity [26]. Hourly averages or sums of microclimatic date were further processed to match the dendrometer measurements.

\subsection{Modelling of Intra-Annual Stem Growth}

To assess differences in intra-annual stem growth dynamics between elevations and years, we defined the critical dates of stem growth phenology (i.e., timings of onset, peak and offset) and estimated growth rates and annual increments from individual dendrometer records. While detecting of growth initiation and cessation from dendrometer-based stem radial variations likely to be confounded by hydrological processes in stems, the estimations should be considered as proxies of seasonal stem growth dynamics $[16,23,27,29,32]$. In subtropics, the high winter air-temperature (above $-4{ }^{\circ} \mathrm{C}$ ) yields little shrinkage of stem radius [21], and soil temperature and moisture are generally optimal for root water uptake during winters (in this study, soil temperature $>4{ }^{\circ} \mathrm{C}$ and soil water content $>0.18 \mathrm{~m}^{3}$ $\mathrm{m}^{-3}$ across sites), implying the absence of pronounced tree water deficit and spring rehydration in tree stems. Additionally, the histological investigation (i.e., micro-coring method) has demonstrated an inactive period with semi-dormancy in subtropical pine forests in January [22]. Given the longer growing seasons and the absence of pronounced winter shrinkage of stem radius for conifer trees in subtropical China [21,22], the year-round daily maximum values of dendrometer measurements across trees and elevations were fitted with Gompertz equations using non-linear regressions [21,23], defined as follows:

$$
y=y_{0}+A \exp \left[-e^{(\beta-\kappa \mathfrak{t})}\right]
$$

with $y$ as daily maximum stem radius, $\mathrm{t}$ as day of the year (DOY), $A$ and $y_{0}$ as upper and lower asymptotes, $\beta$ as axis placement parameter and $\kappa$ as rate of change parameter. The parameter estimations were computed with ordinary least squares method (SAS 9.1, SAS Institute, Cary, NC, USA).

For each individual tree and year, we defined stem growth onset and offset as the dates when $5 \%$ and $95 \%$ of the annual increment were reached [16], respectively, and growth duration as the difference between onset and offset. The parameters of Gompertz models can be used to describe growth rates and its inflection points. Specifically, the maximum growth rate $\left(r_{\max }\right)$, mean growth rate $\left(r_{\text {mean }}\right.$, accounting for $90 \%$ of annual increment) and timing of maximum growth $\left(t_{\text {peak }}\right)$ were calculated for each tree and year as follows [30,34]:

$$
\begin{gathered}
\mathrm{t}_{\text {peak }}=\beta / \kappa \\
r_{\text {max }}=\kappa A / e \\
r_{\text {mean }} \approx 9 / 40 e r_{\text {max }}
\end{gathered}
$$

\subsection{Extractions of Stem Radial Increment and Tree Water Deficit}

Dendrometer-based stem radial variation is jointly determined by irreversible stem radial growth and reversible stem water relations. To examine the microclimatic forcing of intra-annual stem growth and investigate how seasonal drought affected tree water status along the elevational gradient, we adopted the definitions by Zweifel et al. [14] to disentangle stem radial increment and dendrometer-derived tree water deficit (TWD) from raw dendrometer data for each tree and year. More specifically, a stepwise growth curve under the assumption of zero growth during periods of 
stem shrinkage was extracted by moving daily maximum stem radius to the next equal stem radius. Daily pre-dawn TWD, which was considered as a surrogate of canopy tree water status throughout the growing season [19], was calculated as the difference between the potential maximum stem radius (i.e., the current growth curve) and maximum radius on each day. Briefly, we simply assumed that stem radial growth only occurs when stem water is fully saturated (i.e., TWD $=0$ ), while negative values of TWD indicates water stress in tree stems. All dendrometer data analysis was performed throughout the growing season (March-November) in both years. Because absolute values of TWD strongly varied within individual trees of Taiwan pine and across elevations, we therefore normalized TWD by dividing daily TWD for each sampled tree by the largest tree-specific TWD value [19]. As we were interested in comparing growth-climate relationships and tree water statue among elevations, the daily stem radial increment and normalized TWD of sampled trees at each elevation were averaged for the subsequent analysis.

\subsection{Statistical Analysis}

Differences in critical dates of stem growth phenology (timings of onset, peak, and offset), maximum and mean growth rates, and annual increments among three elevations were analyzed by one-way analysis of variance and the Tukey-Kramer comparison (the Tukey-Kramer was applied when group sizes are unequal). Differences of critical dates of stem growth phenology, maximum and mean growth rates and annual increment between 2017 and 2018 were tested by independent samples $t$-test. In pooled data of observed years, partial correlation analysis of multiple linear regression was performed for examining the relative importance of the growth initiation and cessation and mean growth rate to annual increment at each elevation.

To investigate whether there was consistent or variable responses over the growing seasons and among different sites [21], in pooled data of observed years for each elevation, the Spearman correlations between daily stem radial increment and TWD and microclimatic factors were separately determined for wet (March-June) and dry seasons (July-October). As the non-normal distribution of precipitation and soil moisture, nonparametric Spearman correlation coefficients were calculated.

All statistical analysis were conducted with the SPSS 16.0 for windows (SPSS Inc., Chicago, IL, USA), and all significant differences were taken at $p<0.05$.

\section{Results}

\subsection{Climate in 2017 and 2018}

The study area was characterized by distinct climate seasonality, with a wet season from March to June and a dry season from July to September (Table 2, Figure 1). At each site, there was a comparable annual mean air temperature (differences $<0.3 \mathrm{~K}$ ) in 2017 and 2018, whereas less precipitation (137-335 $\mathrm{mm}^{-1} \mathrm{ear}^{-1}$ ) was received in 2018 than in 2017. Moreover, the fraction of dry-season precipitation was greatly reduced in 2018 as compared with 2017 across all sites (24\%-30\% in 2018 versus 34\%-43\% in 2017), but the mean wet-season air temperature in 2018 was $1.5-1.8^{\circ} \mathrm{C}$ higher than in 2017 (Table 2).

Table 2. Summary of climatic variables for the year, wet-season (March-June) and dry-season (July-September) at the three sites during years 2017 and 2018.

\begin{tabular}{|c|c|c|c|c|c|c|c|c|c|c|c|c|c|}
\hline \multirow{2}{*}{ Months } & \multirow{2}{*}{ Year } & \multicolumn{4}{|c|}{$921 \mathrm{~m}$} & \multicolumn{4}{|c|}{$1170 \mathrm{~m}$} & \multicolumn{4}{|c|}{$1402 \mathrm{~m}$} \\
\hline & & $\mathbf{T}_{\mathbf{a}}$ & $\operatorname{Pr}$ & SWC & VPD & $\mathbf{T}_{\mathrm{a}}$ & $\operatorname{Pr}$ & SWC & VPD & $\mathbf{T}_{\mathbf{a}}$ & $\operatorname{Pr}$ & SWC & VPD \\
\hline \multirow{2}{*}{ January-December } & 2017 & 13.3 & 1493 & 0.17 & 0.26 & 12.6 & 1111 & 0.17 & 0.26 & 11.5 & 2343 & 0.30 & 0.19 \\
\hline & 2018 & 13.1 & 1167 & 0.15 & 0.24 & 12.4 & 974 & 0.15 & 0.23 & 11.2 & 2008 & 0.28 & 0.16 \\
\hline \multirow{2}{*}{ March-June } & 2017 & 14.1 & 713 & 0.21 & 0.26 & 13.4 & 591 & 0.20 & 0.27 & 12.2 & 1040 & 0.33 & 0.19 \\
\hline & 2018 & 15.9 & 559 & 0.18 & 0.27 & 15.0 & 487 & 0.18 & 0.25 & 13.7 & 1006 & 0.31 & 0.16 \\
\hline \multirow{2}{*}{ July-September } & 2017 & 22.5 & 595 & 0.15 & 0.33 & 21.6 & 374 & 0.17 & 0.26 & 20.1 & 1006 & 0.31 & 0.13 \\
\hline & 2018 & 22.1 & 280 & 0.11 & 0.30 & 21.1 & 291 & 0.14 & 0.24 & 19.6 & 584 & 0.26 & 0.11 \\
\hline
\end{tabular}

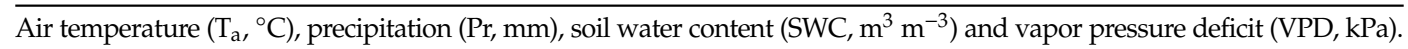




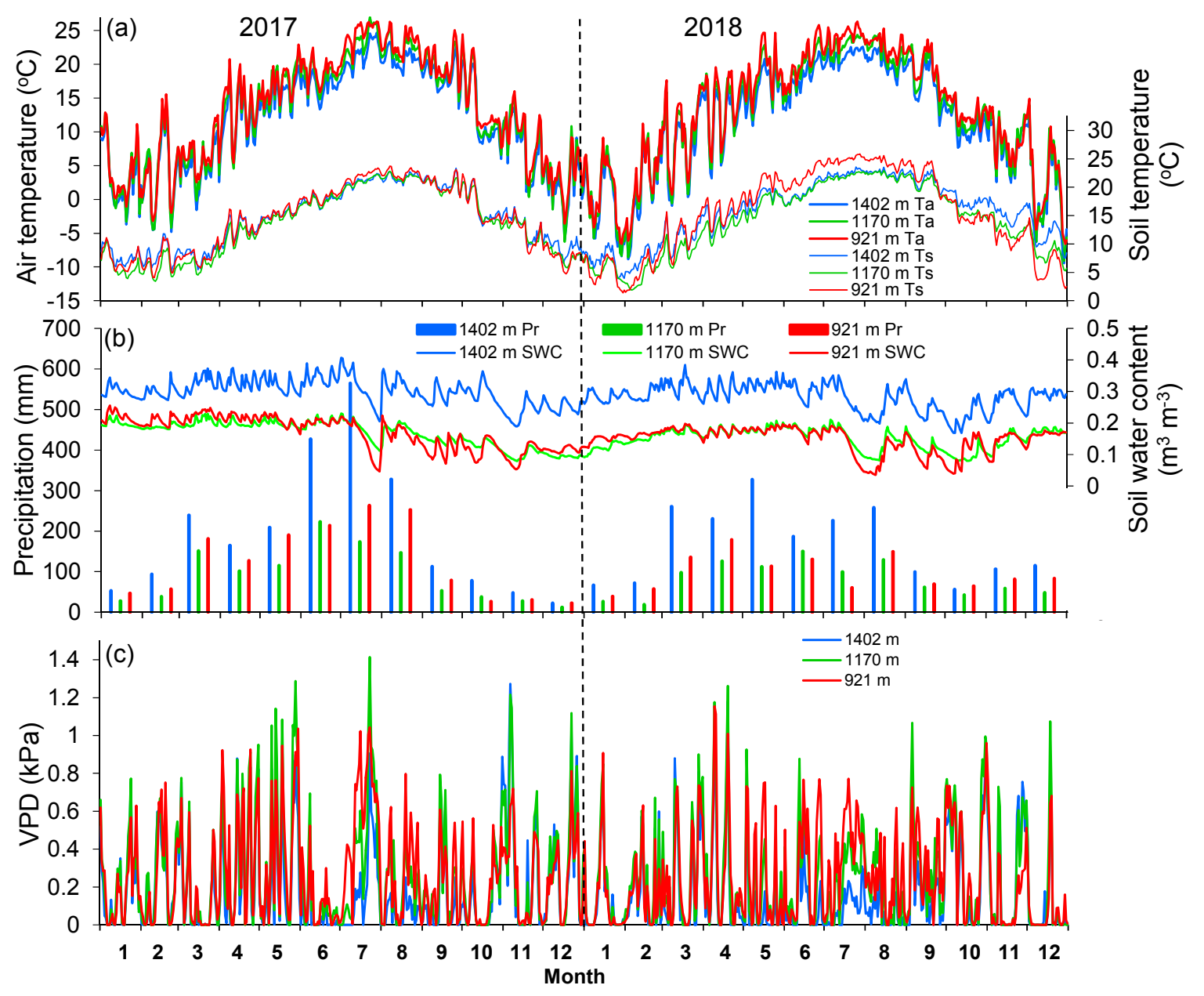

Figure 1. Annual courses of (a) daily mean air $\left(\mathrm{T}_{\mathrm{a}}\right)$ and soil $\left(\mathrm{T}_{\mathrm{s}}\right)$ temperatures, $(\mathbf{b})$ monthly precipitation sums (Pr) and daily mean soil water content (SWC), and (c) vapor pressure deficit (VPD) at the three sites in the Lushan Mountains during 2017 and 2018.

The microclimatic variables recorded during 2017-2018 substantially varied along the elevation gradient. Air temperature for the year, wet-, and dry-seasons linearly decreased by $0.38,0.42$, and $0.51{ }^{\circ} \mathrm{C} / 100 \mathrm{~m}$, respectively $(p<0.01$, from Table 2; Figure 1a). Precipitation for the year, wetand dry-seasons, however, non-significantly increased with elevation by 172,79 and $73 \mathrm{~mm} / 100 \mathrm{~m}$, respectively $(p>0.05)$, because precipitation was reduced at the intermediate site (Table 2, Figure 1b). Consequently, soil water content across seasons and years was generally similar between 921 and 1170 $\mathrm{m}$, while it was consistently higher at $1402 \mathrm{~m}$ (Table 2, Figure 1b). Vapor pressure deficit also decreased with elevation, with a stronger linear decrease in dry season $(0.04 \mathrm{kPa} / 100 \mathrm{~m}$; Table 2, Figure 1c). Across sites, soil temperature was generally above $5{ }^{\circ} \mathrm{C}$ during the study period, and showed no obvious elevational trend.

\subsection{Elevational Variations in Intra-Annual Stem Growth Dynamics and Tree Water Deficit}

In both years, dendrometer records and extracted stem radial increment showed an increasingly suppressed tree growth of Taiwan pine towards the lower elevation (Figure 2a-d). Stem growth at $921 \mathrm{~m}$ ceased around DOY 200 (circa 20 days after the start of dry season) and stem radius largely fluctuated during dry seasons in two years. In contrast, a continued increase of stem radius until DOY 260-310 was observed at the two higher elevations, though a plateau or marked decrease for 20-30 days since early July was also present. Correspondingly, substantial TWD was continuously detected since early July at $921 \mathrm{~m}$, which was more pronounced in 2018 (Figure 2e,f). While such 
large dry-season shrinkage of tree stems also occurred at the two higher elevations, tree stems could frequently rehydrate (i.e., TWD $=0$ ) during dry periods (Figure 2e,f).
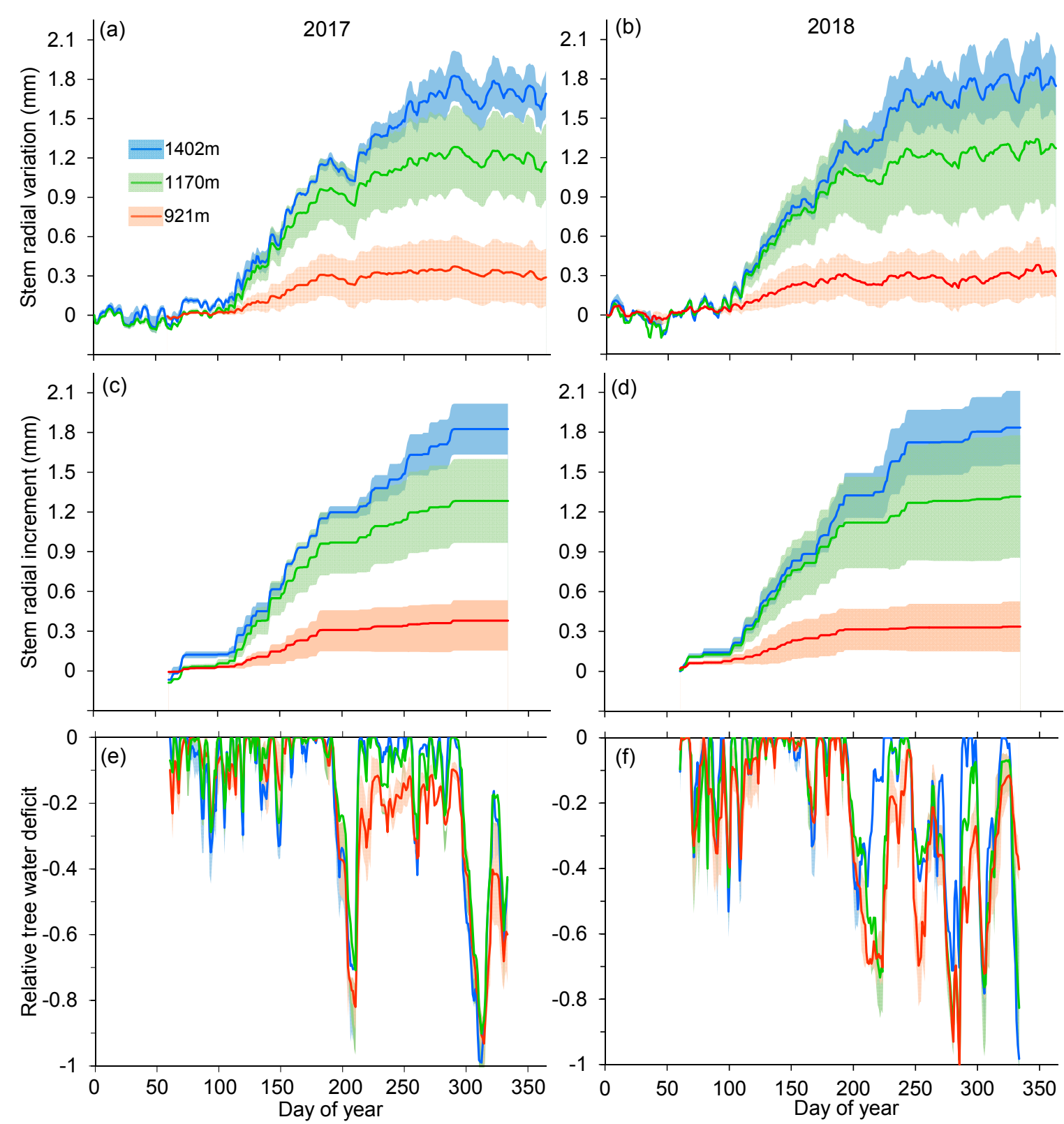

Figure 2. Site average $( \pm S D)$ of $(\mathbf{a}, \mathbf{b})$ stem radial variation (daily maximum dendrometer records), (c,d) cumulative stem radial increment (calculated according to zero-growth conception by Zweifel et al. [14]), and $(\mathbf{e}, \mathbf{f})$ relative tree water deficit (calculated using daily maximum dendrometer records, reflecting pre-dawn tree water status; see methods) at the three sites during 2017 and 2018. Shaded areas indicate standard deviation.

Nonlinear Gompertz equations explained well the variations in dendrometer measurements across sites and years $\left(R^{2}=0.97-0.99\right.$; Table 3, Figure S1). There was no significant difference in the onset of stem growth among elevations both in 2017 and $2018(p>0.05$, Table 4). On average, stem growth among all elevations started in early April (DOY 95-102) in 2017 and at the end of March (DOY 86-89) in 2018 (Table 4, Figure 3a). Maximum stem growth synchronously occurred in mid-May (DOY 138-140) in 2017 and in early May (DOY 128-131) in 2018 at the two lower sites, while it was delayed by about two weeks (DOY 151 and 144 in 2017 and 2018, respectively) at the highest site $(p<0.05$; Table 4, Figure 3a). Impressively, the offset of stem growth among elevations in both years differed by up to 106 
days ( $p$ < 0.05), ranging from late July (DOY 212 and 206 in 2017 and 2018, respectively) at the lowest site to early November (DOY 310 and 312 in 2017 and 2018, respectively) at the highest site (Table 4, Figure 3a). Within a site, no differences in critical dates for stem growth were observed between years, except for the intermediate site. In addition, mean temperatures during the week before the onset of stem growth exhibited an elevation-dependent threshold, varying from 7.7 to $12.7^{\circ} \mathrm{C}$ for mean air temperature and from 4.4 to $8.9^{\circ} \mathrm{C}$ for mean minimum air temperature. The ending of stem growth at the lowest site coincided with the occurrence of high temperature $\left(24.8-25.8^{\circ} \mathrm{C}\right)$ and low soil water availability $\left(0.06-0.07 \mathrm{~m}^{3} \mathrm{~m}^{-3}\right)$ in both years, whereas water stress was absent during the ending of stem growth at the two higher sites (Table 4).

Table 3. Parameters (mean $\pm \mathrm{SD}$ ) and $R^{2}$ of Gompertz functions for intra-annual stem growth dynamic at three sites in 2017 and 2018.

\begin{tabular}{|c|c|c|c|c|c|c|c|c|}
\hline Year & Sites & $A$ & $\beta$ & $\kappa\left(10^{-2}\right)$ & $y_{0}\left(10^{-2}\right)$ & $R^{2}$ & $r_{\max }\left(\mu \mathrm{m} \mathrm{d}^{-1}\right)$ & $\begin{array}{c}r_{\text {mean }} \\
\left(\mu \mathrm{m} \mathrm{d}^{-1}\right)\end{array}$ \\
\hline \multirow{3}{*}{2017} & $921 \mathrm{~m}$ & $0.38 \pm 0.25$ & $6.20 \pm 3.44$ & $4.56 \pm 2.71$ & $0.47 \pm 1.46$ & 0.98 & $4.79 \pm 1.76^{b}$ & $2.93 \pm 1.08^{b}$ \\
\hline & $1170 \mathrm{~m}$ & $1.26 \pm 0.33$ & $3.85 \pm 0.96$ & $2.77 \pm 0.81$ & $-3.69 \pm 2.42$ & 0.99 & $12.43 \pm 3.52^{\mathrm{a}}$ & $7.60 \pm 2.15^{a}$ \\
\hline & $1402 \mathrm{~m}$ & $1.77 \pm 0.21$ & $2.92 \pm 0.23$ & $1.93 \pm 0.18$ & $-0.36 \pm 3.40$ & 0.99 & $12.55 \pm 1.50^{a}$ & $7.67 \pm 0.92^{\mathrm{a}}$ \\
\hline \multirow{3}{*}{2018} & $921 \mathrm{~m}$ & $0.28 \pm 0.18$ & $4.33 \pm 2.86$ & $3.59 \pm 2.08$ & $1.07 \pm 2.19$ & 0.97 & $3.60 \pm 2.11^{\mathrm{B}}$ & $2.20 \pm 1.29^{B}$ \\
\hline & $1170 \mathrm{~m}$ & $1.28 \pm 0.49$ & $3.38 \pm 0.55$ & $2.66 \pm 0.53$ & $-2.04 \pm 1.64$ & 0.99 & $11.99 \pm 3.53^{\mathrm{A}}$ & $7.33 \pm 2.16^{A}$ \\
\hline & $1402 \mathrm{~m}$ & $1.84 \pm 0.27$ & $2.71 \pm 0.09$ & $1.88 \pm 0.04$ & $-1.54 \pm 0.64$ & 0.99 & $12.73 \pm 1.92^{\mathrm{A}}$ & $7.79 \pm 1.17^{\mathrm{A}}$ \\
\hline
\end{tabular}

$A$ upper asymptote, $\beta x$-axis placement, $\kappa$ rate of change, $y_{0}$ lower asymptotes, $r_{\max }$ maximum growth rate, $r_{\text {mean }}$ mean growth rate. Different letters indicate significant differences in $r_{\text {max }}$ and $r_{\text {mean }}$ among elevations in 2017 (lowercase) and 2018 (uppercase) at $p<0.05$.

Table 4. Critical dates (DOY, day of the year; mean \pm SD) of intra-annual stem growth, mean, and minimum air temperatures $\left(T_{a}, T_{a \_m i n}\right)$ during the week prior to the onset of stem growth, and mean air temperature and soil water content (SWC) and precipitation sums (Pr) during the week before the offset of stem growth at the three sites in 2017 and 2018.

\begin{tabular}{|c|c|c|c|c|c|c|c|c|c|}
\hline Year & Sites & $\begin{array}{l}\text { Onset } \\
\text { (DOY) }\end{array}$ & $\begin{array}{c}\text { Peak } \\
\text { (DOY) }\end{array}$ & $\begin{array}{l}\text { Offset } \\
\text { (DOY) }\end{array}$ & $\begin{array}{c}T_{a} \text { at } \\
\text { Onset }\end{array}$ & $\begin{array}{c}T_{\text {a_min }} \text { at } \\
\text { Onset }\end{array}$ & $\begin{array}{l}T_{a} \text { at } \\
\text { Offset }\end{array}$ & $\begin{array}{l}\text { Pr at } \\
\text { Offset }\end{array}$ & $\begin{array}{l}\text { SWC at } \\
\text { Offset }\end{array}$ \\
\hline \multirow{3}{*}{2017} & $921 \mathrm{~m}$ & $102 \pm 10^{a}$ & $138 \pm 5^{b}$ & $212 \pm 15^{c}$ & 12.4 & 8.6 & 25.8 & 0 & 0.06 \\
\hline & $1170 \mathrm{~m}$ & $99 \pm 5^{a}$ & $140 \pm 8^{a b}$ & $273 \pm 15^{b}$ & 9.3 & 5.7 & 20.1 & 23.6 & 0.15 \\
\hline & $1402 \mathrm{~m}$ & $95 \pm 7^{a}$ & $151 \pm 8^{a}$ & $310 \pm 11^{a}$ & 7.7 & 4.5 & 9.6 & 1.4 & 0.23 \\
\hline \multirow{3}{*}{2018} & $921 \mathrm{~m}$ & $89 \pm 9^{A}$ & $131 \pm 11^{B}$ & $206 \pm 14^{C}$ & 12.7 & 8.9 & 24.8 & 0 & 0.07 \\
\hline & $1170 \mathrm{~m}$ & $86 \pm 3^{A}$ & $128 \pm 6^{B}$ & $260 \pm 8^{B}$ & 9.5 & 6.7 & 18.1 & 11 & 0.12 \\
\hline & $1402 \mathrm{~m}$ & $86 \pm 6^{A}$ & $144 \pm 6^{\mathrm{A}}$ & $312 \pm 12^{\mathrm{A}}$ & 7.8 & 4.4 & 10.2 & 27.6 & 0.22 \\
\hline
\end{tabular}

Different letters indicate significant differences in timings of onset, peak, and offset among elevations in 2017 (lowercase) and 2018 (uppercase) at $p<0.05$. Bold characters indicate significant differences between years at $p<0.05$.

The maximum $\left(r_{\max }\right)$ and mean $\left(r_{\text {mean }}\right)$ growth rates between the two higher sites were not significantly different in both years, but were 2.6 (2017) and 3.3 (2018) times greater than at the lowest site $(p<0.05$; Table 3$)$. Accordingly, there was a significant difference in annual increments among three elevations in both years $(p<0.05)$, ranging from $0.38(921 \mathrm{~m})$ to $1.77 \mathrm{~mm}(1402 \mathrm{~m})$ and from 0.27 (921 m) to $1.85 \mathrm{~mm}$ (1402 m) in 2017 and 2018, respectively (Figure 3b). Within a site, no differences in $r_{\max }, r_{\text {mean }}$ and annual increment were found between years. For each site, the timings of stem growth onset and offset, and $r_{\text {mean }}$ were not correlated $(p>0.05)$. Thus, partial correlation analysis indicated that the date of stem growth offset mainly determined the variations of annual increment at the lowest site, while annual increment at the two higher sites was mainly limited by $r_{\text {mean }}$ (Table 5). 
Table 5. Partial correlation coefficients of multiple linear regressions for relationships of annual increments to intra-annual stem growth parameters across the three sites.

\begin{tabular}{ccccc}
\hline Independent Variables & $\mathbf{9 2 1} \mathbf{~ m}$ & $\mathbf{1 1 7 0 ~} \mathbf{~}$ & $\mathbf{1 4 0 2} \mathbf{~ m}$ & All \\
\hline Timing of growth onset (DOY) & -0.64 & -0.54 & -0.35 & -0.22 \\
Timing of growth offset (DOY) & $0.97^{*}$ & $0.83^{*}$ & 0.53 & $0.75^{* * *}$ \\
Mean growth rate $\left(\mu \mathrm{m} \mathrm{d}^{-1}\right)$ & 0.78 & $0.91^{* *}$ & $0.85^{*}$ & $0.87^{* * *}$ \\
\hline${ }^{*} p<0.05,{ }^{* *} p<0.01,{ }^{* * *} p<0.001$. & &
\end{tabular}
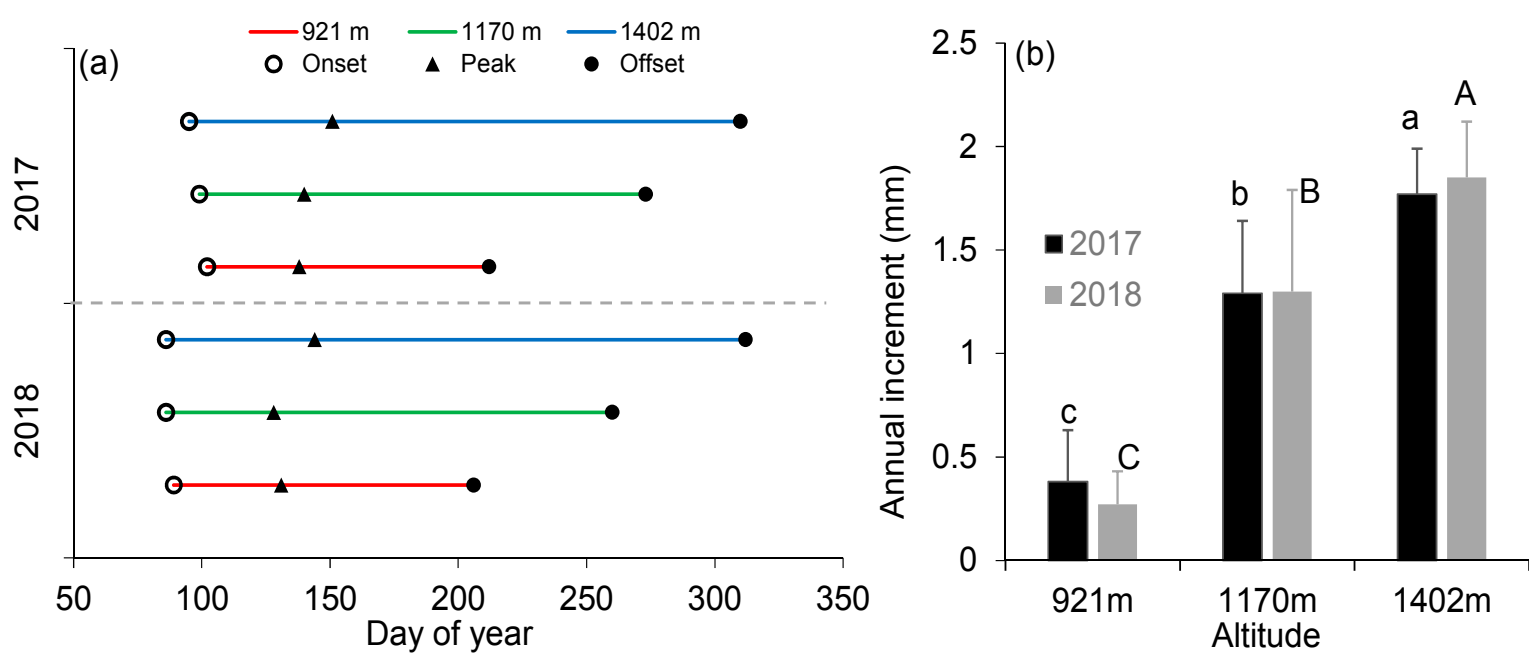

Figure 3. Dates of (a) stem growth onset, peak, and offset, and (b) annual increments derived from fitted Gompertz functions during 2017-2018. Different letters indicate significant differences in annual increment among elevations in 2017 (lowercase) and 2018 (uppercase) at $p<0.05$. Error bars indicate \pm SD of mean.

\subsection{Correlations of Stem Radial Increment and Tree Water Deficit versus Microclimatic Variables}

The growth-limiting factors differed between the wet (March-June) and dry (July-October) season at the two higher sites, but was generally consistent across seasons at the lower site (Figure $4 \mathrm{a}-\mathrm{c}$ ). At the two higher sites, wet-season stem radial increments were significantly positively correlated with all temperature variables, whereas precipitation and soil water content showed the highest correlations with dry-season stem radial increments. At the lowest site, however, stem radial increments in both wet and dry seasons were mainly affected by moisture (precipitation and soil water content) and water demand (vapor pressure deficit) variables, indicating a higher growth-moisture dependency throughout the growing season.

Non-season-specific TWD-microclimate relationships were found across the three sites, while TWD consistently displayed a higher sensitivity to dry-season moisture (precipitation and soil water content) and water demand (vapor pressure deficit) conditions than to wet-season (Figure $4 \mathrm{~d}-\mathrm{f}$ ). Furthermore, the sensitivity of TWD to microclimatic factors decreased with elevation in both wetand dry-seasons. 

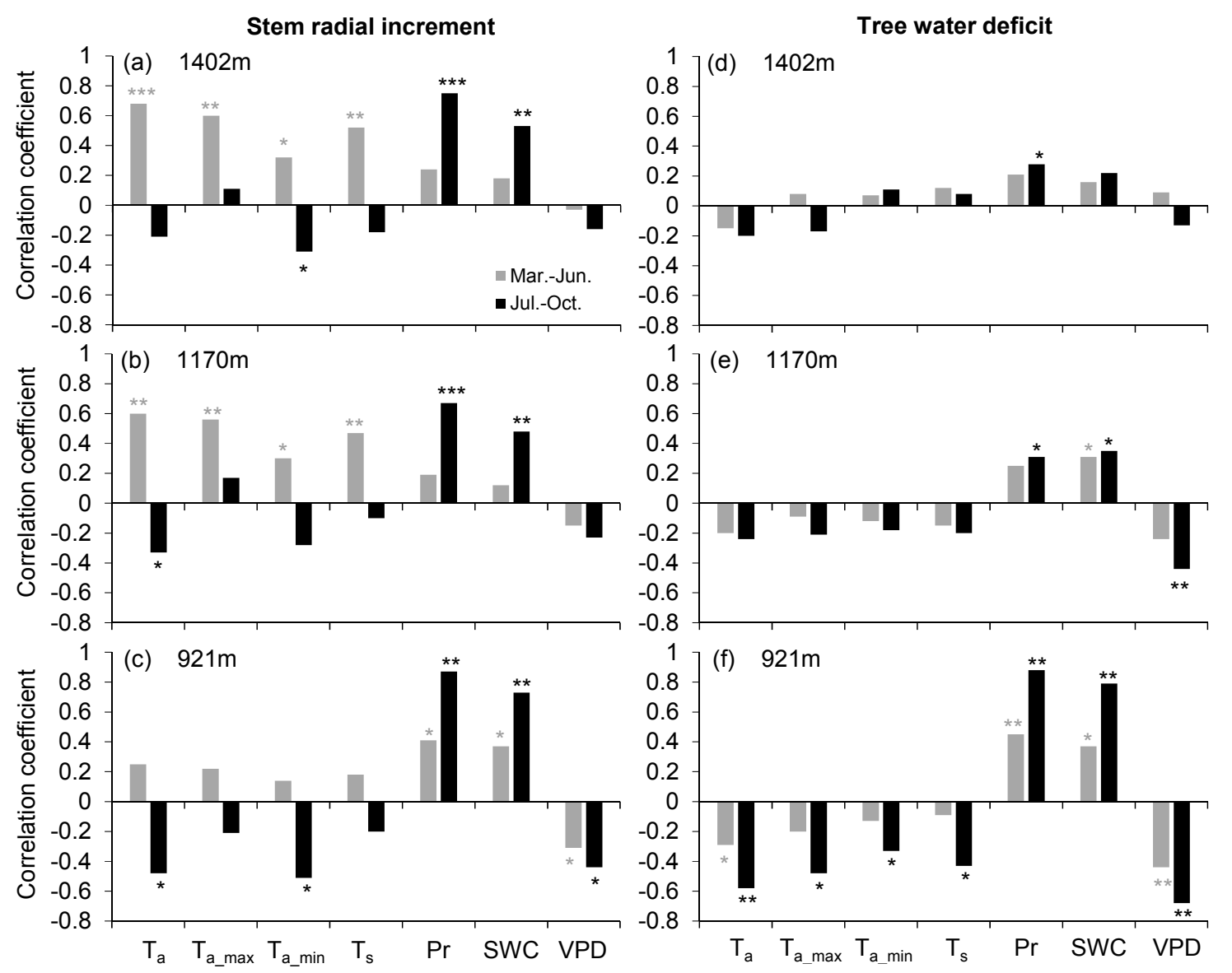

Figure 4. Spearman correlation coefficients between $(\mathbf{a}-\mathbf{c})$ daily stem radial increment and $(\mathbf{d}-\mathbf{f})$ tree water deficit and environmental variables during wet (March-June) and dry (July-October) seasons at the three sites in 2017 and 2018. Mean air temperature $\left(\mathrm{T}_{\mathrm{a}}\right)$, maximum air temperature $\left(\mathrm{T}_{\mathrm{a} \_\max }\right)$, minimum air temperature $\left(\mathrm{T}_{\mathrm{a} \_ \text {min }}\right)$, mean soil temperature $\left(\mathrm{T}_{\mathrm{s}}\right)$, precipitation $(\mathrm{Pr})$, soil water content (SWC), and vapor pressure deficit (VPD). Asterisks indicate significance levels ${ }^{*} p<0.05,{ }^{* *} p<0.01$, and $\left.{ }^{* * *} p<0.001\right)$.

\section{Discussion}

\subsection{Intra-Annual Stem Growth Dynamics along the Elevation Transect}

Elevational gradients provide a natural 'space-for-time' substitution to investigate the mechanism of intra-annual stem growth in response to future climate change [24-29,32]. In this study, stem radial variation of Taiwan pine was monitored along an elevation transect in subtropical China, which covered diverse climatic growing conditions ranging from the low-elevation dry edge to high-elevation cool and humid environment for this species. The elevational pattern of intra-annual stem growth dynamics was characterized by a roughly parallel onset but a substantially delayed offset with increasing elevations, resulting in the shortest growing season at the lowest elevation. Such a drought-induced elevational pattern of cambial phenology has been recently observed in water-limited forests [25,26,29,32].

The synchronized starting of stem growth across elevations is consistent with the elevational transect investigations in semi-arid mountains [25,29], but contrasts with results from cold-limited forests [24,26-28,35]. Temperature has been long recognized as the major trigger of the growth initiation of coniferous and broadleaf trees across temperate and boreal forests $[17,24,27,28]$, and most studies have repeatedly reported that a physiological threshold daily minimum temperature of $\geq$ $4-5{ }^{\circ} \mathrm{C}$ is related to cambial reactivation and xylem cell differentiation [17]. Although both mean and minimum air temperatures during the week prior to the onset of stem growth differed greatly 
among elevations, these averaged temperatures varied little between years at each elevation (mean air temperature of $12.4-12.7^{\circ} \mathrm{C}, 9.3-9.5^{\circ} \mathrm{C}$, and $7.7-7.8^{\circ} \mathrm{C}$ at 921,1170 , and $1402 \mathrm{~m}$, respectively; and minimum air temperature of $8.6-8.9^{\circ} \mathrm{C}, 5.7-6.7^{\circ} \mathrm{C}$, and $4.4-4.5^{\circ} \mathrm{C}$ at 921,1170 , and $1402 \mathrm{~m}$, respectively), suggesting an elevation-specific temperature threshold for growth initiation. Our results are similar to the observation of low-elevation Pinus massoniana in subtropical China, where a higher temperature threshold for cambial activity was recorded [22]. Additionally, growing degree-days above $5{ }^{\circ} \mathrm{C}$ at the onset of stem growth tended to decreased with increasing elevations (data not shown). It has been demonstrated that forcing and chilling temperatures both play an important role in determining the spring resumption of xylem in Northern Hemisphere conifers, and trees growing under warmer conditions commonly need a higher forcing temperature to trigger wood formation [36]. Such an interactive mechanism might explain the elevation-specific temperature threshold for Taiwan pine and the parallel onset of stem growth among elevations. In addition, photoperiod is a major driver of seasonal stem growth, but a potential interplay between spring temperature and photoperiod as modulators of onset of stem growth has remained unexplored. As a result, the 9-13 days earlier onset of stem growth in 2018 compared to 2017 across the three elevations was directly attributed to the warmer March temperatures in 2018 (averaged across sites, $4.3^{\circ} \mathrm{C}$ in 2017 versus $9.1^{\circ} \mathrm{C}$ in 2018).

Our study showed a most significant difference in the timing of stem growth offset over the elevation transect, with 3 months earlier at the lowest site compared with the highest site (late July versus early November). Although dendrometer data and Gompertz modeling do not allow direct determining the end of stem growth, several micro-coring studies on wood formation along elevation gradients in semi-arid and temperate forests reported that stem growth cessation at the lower elevations was hastened by increased drought stress $[25,26]$, whereas the elevation effects on stem growth cessation generally disappeared under non-water-limited environments [24,28]. At the cellular level, there is evidence that drought could delay cambial activity despite optimal thermal conditions in drought-prone areas [30,31]. Additionally, irrigation and natural experiments on mature trees found that the irrigated trees/dry-mesic site finished wood formation later than the unirrigated trees/xeric site $[37,38]$, confirming the critical role of water availability on stem growth cessation. In this study, the concurrent high temperature and low soil water availability seemed to trigger the offset of stem growth at the lowest site, leading to a substantial and continuous tree water deficit since early July (i.e., the beginning of seasonal drought), which indicated a severe and long-lasting water stress during the dry periods. Conversely, the frequent rehydration of tree stems during dry periods at the two higher sites clearly suggested that seasonal drought appeared to have less influence on high-elevation stem growth offset. It should be note that Taiwan pine at the most stressed site experienced the least absolute stem shrinkage as compared to two higher sites, which was mostly related to water-saving behavior through early stomatal closure under increasing dry-season evaporative demand. Consequently, the ending of high-elevation stem growth was greatly delayed, while it is probably controlled by photoperiod and internal plant hormones [24,26]. Thus, the much lower amount of dry-season rainfall and soil water content in 2018 induced an earlier cessation of stem growth than in 2017 at the two lower elevations, but not at the highest elevation.

\subsection{Seasonal Drought Effects on Stem Radial Growth}

The observed seasonal shift in growth-limiting factors from temperatures in wet season to precipitation and soil water content in dry season at the two higher elevations corresponds to our previous findings [21], whereas a higher growth-moisture dependency over the whole growing season was found at the lowest elevation. The wet-season moisture constraint on tree-ring width of Taiwan pine and Bashan fir (Abies fargesii) in subtropical China was also demonstrated by dendrochronological studies, where warming-induced drought was detected in the early growing season [6,39]. Nevertheless, our results contrast with the non-elevation effects on growth-climate relationships in semi-arid [27,29] and cold-limited forests [35]. Physiologically, xylem cell enlargement and stem radial growth is a turgor-driven process, which requires a continuous maintenance of stem water saturation [30,31]. 
In this study, the higher sensitivity of tree water status (reflected by tree water deficit) to moisture variables at the lowest elevation might explain why low-elevation stem radial growth was highly dependent on precipitation and soil water content.

Moreover, a comparable annual increment was achieved between years at each of the two higher elevations, which was mainly ascribed to the contrasting intra-annual variations in climatic conditions. The warmer wet season in 2018 translated into producing a larger proportion of the annual growth compared to the cooler wet season in 2017 (73\%-88\% in 2018 versus 66\%-75\% in 2017); however, stem radial growth was greatly reduced due to the reduced dry-season precipitation in 2018. Under the seasonal drought condition in subtropical China, our findings therefore highlight that the high-elevation total ring width is mostly relied on the balance between the stimulating effects of wet-season temperature and the limiting effects of dry-season precipitation. The changing seasonal combination of temperature and precipitation and its differential impacts on stem radial growth might also provide a mechanical explanation for the complicated growth-climate relationships in subtropical forest $[3-12,21,40]$. By contrast, since stem radial growth was consistently positively related to moisture variables over the growing season at the lowest elevation, a wider annual growth in 2017 compared to 2018 was probably attributed to the more humid year 2017.

We found that Taiwan pine produced very narrow total ring widths at the lower edge, 4.7-6.9 times narrower than that at the highest elevation. Seasonal droughts can exert multiple influences on tree growth. One way is to directly limit cambial cell division and enlargement (i.e., growth rates) by modulating cell turgor $[30,31]$. The other major way is to indirectly shorten the growing season by causing an exceptionally early growth cessation $[37,38]$, which has been demonstrated in low-elevation European larch within dry Alpine regions [32]. The cambial division and secondary xylem cells differentiation require a continuous supply of sucrose converted from photoassimilate [41]. The observed seasonal drought-induced substantial tree water deficit of low-elevation Taiwan pine might lead to stomatal closure and consequent reduction of sucrose, resulting in an exceptionally early growth cessation in late July. On the other hand, under extreme drought stress, there is increasing evidence that trees tend to allocate limited resource to stress defense (e.g., belowground root production, primary growth, and reproduction effort) rather than to stem radial growth, which is probably related to regaining physiological functions and reproductive efforts after drought [42-44]. Indeed, the primary growth (needle and shoot elongation) of Taiwan pine started in late April and stopped in late August to early September at the three sites (X.L., unpublished data), suggesting a potential trade-off between radial growth and primary growth for Taiwan pine, particularly at the lowest elevation where the earliest growth cessation with high intensities of seasonal drought was found. Such trade-offs might partly explained the early growth cessation and lower annual growth at the lowest elevation. On the contrary, the higher growth rate and longer growing season of high-elevation Taiwan pine not only benefited from the optimal wet-season environmental conditions, but also was probably promoted by a reactivation of cambial activity due to improvements of moisture conditions during dry periods $[18,21,45,46]$, though again, it is difficult to distinguish cambium reactivation from stem water recharge after summer rains using dendrometer data [47]. As a consequence, the annual growth at two higher elevations was more sensitive to growth rate than to timings of growth onset and offset, supporting the finding that wood formation is mainly determined by growth rate rather than the length of growing season in water-limited environments [28,34,48]. However, the variations of low-elevation annual growth depended more on cessation time than on initiation time and growth rate, highlighting the predominately role of cessation time in controlling annual growth of Taiwan pine under extreme seasonal drought conditions. Finally, tree phenology and growth can also be affected by different genetic structure [49], whether the elevational differences in phenological processes of Taiwan pine are due to epigenetic acclimation or genetic adaptation merits further investigation. 


\section{Conclusions}

Our elevational transect observation of intra-annual stem growth of Taiwan pine confirmed that temperature was the main driver triggering the onset of stem growth, and elevation-specific temperature thresholds shaped the uniform onset of stem growth over elevations. Most importantly, an exceptionally early growth cessation prevailed at the lowest elevation in both years, which was related to seasonal drought-induced substantial and continuous tree water deficit since early July. Furthermore, as compared to the high elevations, a higher growth-moisture dependency over the whole growing season was found at the lowest elevation. Hence, low-elevation Taiwan pine produced a rather narrow annual growth, which was closely attributed to the multiple and strong influences of seasonal drought on growth cessation and rates. Our findings provide insight into phenological basis for predicting the future adaptability and vulnerability of subtropical forest stands with high tree species diversity. In south China, instrumental climatic data and climate projections have consistently indicated a warmer and drier climate since the 1980s, owing to the changing precipitation seasonality [2,50]. As Taiwan pine commonly co-occurs with more competitive and drought-tolerant broad-leaved tree species at the dry edge, tree growth decline and even mortality would likely occur in the near future. Furthermore, our findings suggest that the optimal elevation for Taiwan pine growth in southern China is expected to shift upwards in the coming decades. However, given that most of the mountains are lower than 2000 $\mathrm{m}$ and provides limited space for elevational displacement of Taiwan pine, which may fundamentally alter the species composition and ecosystem functions in subtropical China [51].

Supplementary Materials: The following are available online at http://www.mdpi.com/1999-4907/10/12/1128/s1. Figure S1: Observed and modeled stem radial variations of Taiwan pine at three elevations in 2017 and 2018.

Author Contributions: Conceptualization, X.L.; Funding acquisition, X.L.; Investigation, X.L., C.W., and J.Z.; Supervision, X.L.; Writing—original draft, X.L.; Writing—review and editing, X.L., C.W., and J.Z.

Funding: This work was funded by the National Natural Science Foundation of China $(41961008,41561011)$, and the Natural Science Foundation of Jiangxi, China (20192BAB203021). X.L. is grateful for the support from the China Scholarship Council.

Acknowledgments: We are grateful to Franco Biondi for helpful suggestions on an earlier draft of the manuscript and English editing. We also extend our gratitude to Siyu Wu and Lulu Cai for helping with field investigations. In addition, we would like to thank two anonymous reviewers for their insightful comments and suggestions for improving the quality of the paper.

Conflicts of Interest: The authors declare no conflict of interest.

\section{References}

1. Allen, C.D.; Macalady, A.K.; Chenchouni, H.; Bachelet, D.; McDowell, N.; Vennetier, M.; Kitzberger, T.; Rigling, A.; Breshears, D.D.; Hogg, E.H.; et al. A global overview of drought and heat-induced tee mortality reveals emerging climate change risks for forest. For. Ecol. Manag. 2010, 259, 660-684. [CrossRef]

2. Zhou, G.; Wei, X.; Wu, Y.; Liu, S.; Huang, Y.; Yan, J.; Zhang, D.; Zhang, Q.; Liu, J.; Meng, Z.; et al. Quantifying the hydrological responses to climate change in an intact forested small watershed in Southern China. Glob. Chang. Biol. 2011, 17, 3736-3746. [CrossRef]

3. Shi, J.; Cook, E.R.; Lu, H.; Li, J.; Wright, W.E.; Li, S. Tree-ring based winter temperature reconstruction for the lower reaches of the Yangtze River in southeast China. Clim. Res. 2010, 41, 169-175. [CrossRef]

4. $\quad$ Duan, J.; Zhang, Q.-B.; Lv, L.; Zhang, C. Regional-scale Winter-spring temperature variability and chilling damage dynamics over the past two centuries in southeastern China. Clim. Dyn. 2012, 39, 919-928. [CrossRef]

5. Zheng, Y.; Zhang, Y.; Shao, X. Temperature variability inferred from tree-ring widths in the Dabie Mountains of subtropical central China. Trees 2012, 26, 1887-1894. [CrossRef]

6. Dang, H.; Zhang, Y.; Zhang, K.; Jiang, M.; Zhang, Q. Climate-growth relationships of subalpine fir (Abies fargesii) across the altitudinal range in the Shennongjia Mountains, central China. Clim. Chang. 2013, 117, 903-917. [CrossRef]

7. Cai, Q.; Liu, Y. Two centuries temperature variations over subtropical southeast China inferred from Pinus taiwanensis Hayata tree-ring width. Clim. Dyn. 2017, 48, 1813-1825. [CrossRef] 
8. Cai, Q.; Liu, Y.; Duan, B.; Sun, C. Regional difference of the start time of the recent warming in Eastern China: Prompted by a 165 -year temperature record deduced from tree rings in the Dabie Mountains. Clim. Dyn. 2018, 50, 2157-2168. [CrossRef]

9. Chen, F.; Yuan, Y.J.; Wei, W.S.; Yu, S.L.; Zhang, T.W. Reconstructed temperature for Yong'an, Fujian, Southeast China: Linkages to the Pacific Ocean climate variability. Glob. Planet. Chang. 2012, 86, 11-19. [CrossRef]

10. Li, Y.; Fang, K.; Cao, C.; Li, D.; Zhou, F.; Dong, Z.; Zhang, Y.; Gan, Z. A tree-ring chronology spanning 210 years in the coastal area of southeastern China, and its relationship with climate change. Clim. Res. 2016, 67, 209-220. [CrossRef]

11. Cai, Q.; Liu, Y.; Liu, H.; Sun, C.; Wang, Y. Growing-season precipitation since 1872 in the coastal area of subtropical southeast China reconstructed from tree rings and its relationship with the East Asian summer monsoon system. Ecol. Indic. 2017, 82, 441-450. [CrossRef]

12. Luo, D.; Huang, J.-G.; Jiang, X.; Ma, Q.; Liang, H.; Guo, X.; Zhang, S. Effect of climate and competition on radial growth of Pinus massoniana and Schima superba in China's subtropical monsoon mixed forest. Dendrochronologia 2017, 46, 24-34. [CrossRef]

13. Deslauriers, A.; Morin, H.; Urbinati, C.; Carrer, M. Daily weather response of balsam fir (Abies balsamea (L.) Mill.) stem radius increment from dendrometer analysis in the boreal forests of Québec (Canada). Trees Struct. Funct. 2003, 17, 477-484. [CrossRef]

14. Zweifel, R.; Haeni, M.; Buchmann, N.; Eugster, W. Are trees able to grow in periods of stem shrinkage? New Phytol. 2016, 211, 839-849. [CrossRef]

15. Mencuccini, M.; Salmon, Y.; Mitchell, P.; Hölttä, T.; Choat, B.; Meir, P.; O'Grady, A.; Tissue, D.; Zweifel, R.; Sevanto, S.; et al. An empirical method that separates irreversible stem radial growth from bark water content changes in trees: Theory and case studies. Plant Cell Environ. 2017, 40, 290-303. [CrossRef]

16. Van der Maaten, E.; Pape, J.; Van der Maaten-Theunissen, M.; Scharnweber, T.; Smiljanić, M.; Cruz-García, R.; Wilmking, M. Distinct growth phenology but similar daily stem dynamics in three co-occurring broadleaved tree species. Tree Physiol. 2018, 38, 1820-1828. [CrossRef]

17. Rossi, S.; Deslauriers, A.; Gričar, J.; Seo, J.-W.; Rathgeber, C.; Anfodillo, T.; Morin, H.; Levanic, T.; Oven, P.; Jalkanen, R. Critical temperatures for xylogenesis in conifers of cold climates. Glob. Ecol. Biogeogr. 2008, 17, 696-707. [CrossRef]

18. Camarero, J.J.; Olano, J.M.; Parras, A. Plastic bimodal xylogenesis in conifers from continental Mediterranean climates. New Phytol. 2010, 185, 471-480. [CrossRef]

19. Dietrich, L.; Zweifel, R.; Kahmen, A. Daily stem diameter variations can predict the canopy water status of mature temperate trees. Tree Physiol. 2018, 38, 941-952. [CrossRef]

20. Ziaco, E.; Biondi, F. Stem Circadian Phenology of Four Pine Species in Naturally Contrasting Climates from Sky-Island Forests of the Western USA. Forests 2018, 9, 396. [CrossRef]

21. Liu, X.S.; Nie, Y.Q.; Wen, F. Seasonal Dynamics of Stem Radial Increment of Pinus taiwanensis Hayata and Its Response to Environmental Factors in the Lushan Mountains, Southeastern China. Forests 2018, 9, 387. [CrossRef]

22. Huang, J.-G.; Guo, X.; Rossi, S.; Zhai, L.; Yu, B.; Zhang, S.; Zhang, M. Intra-annual wood formation of subtropical Chinese red pine shows better growth in dry season than wet season. Tree Physiol. 2018, 38, 1225-1236. [CrossRef] [PubMed]

23. Fan, Z.-X.; Bräuning, A.; Fu, P.-L.; Yang, R.-Q.; Qi, J.-H.; Grießinger, J.; Gebrekirstos, A. Intra-Annual Radial Growth of Pinus kesiya var. langbianensis Is Mainly Controlled by Moisture Availability in the Ailao Mountains, Southwestern China. Forests 2019, 10, 899. [CrossRef]

24. Moser, L.; Fonti, P.; Büntgen, U.; Esper, J.; Luterbacher, J.; Franzen, J.; Frank, D. Timing and duration of European larch growing season along altitudinal gradients in the Swiss Alps. Tree Physiol. 2010, 30, 225-233. [CrossRef]

25. Ziaco, E.; Biondi, F. Tree growth, cambial phenology, and wood anatomy of limber pine at a Great Basin (USA) mountain observatory. Trees Struct. Funct. 2016, 30, 1507-1521. [CrossRef]

26. Saderi, S.; Rathgeber, C.B.K.; Rozenberg, P.; Fournier, M. Phenology of wood formation in larch (Larix decidua Mill.) trees growing along a 1000-m elevation gradient in the French Southern Alps. Ann. For. Sci. 2019, 76, 89. [CrossRef] 
27. Wang, Z.; Yang, B.; Deslquriers, A.; Bräuning, A. Intra-annual stem radial increment response of Qilian juniper to temperature and precipitation along an altitudinal gradient in northwestern China. Trees Struct. Funct. 2015, 29, 25-34. [CrossRef]

28. Zhang, J.; Gou, X.; Pederson, N.; Zhang, F.; Niu, H.; Zhao, S.; Wang, F. Cambial phenology in Juniperus przewalskii along different altitudinal gradients in a cold and arid region. Tree Physiol. 2018, 38, 840-852. [CrossRef]

29. Gao, J.; Yang, B.; He, M.; Shishov, V. Intra-annual stem radial increment patterns of Chinese pine, Helan Mountains, Northern Central China. Trees Struct. Funct. 2019, 33, 751-763. [CrossRef]

30. Ziaco, E.; Truettner, C.; Biondi, F.; Sarah, B. Moisture-driven xylogenesis in Pinus ponderosa from a Mojave Desert mountain reveals high phenological plasticity. Plant Cell Environ. 2018, 41, 823-836. [CrossRef]

31. Ren, P.; Rossi, S.; Camarero, J.J.; Ellison, A.M.; Liang, E.; Peñuelas, J. Critical temperature and precipitation thresholds for the onset of xylogenesis of Juniperus przewalskii in a semi-arid area of the north-eastern Tibetan Plateau. Ann. Bot. 2018, 121, 617-624. [CrossRef] [PubMed]

32. Obojes, N.; Meurer, A.; Newsely, C.; Tasser, E.; Oberhuber, W.; Mayr, S.; Tappeiner, U. Water stress limits transpiration and growth of European larch up to the lower subalpine belt in an inner-alpine dry valley. New Phytol. 2018, 220, 460-475. [CrossRef] [PubMed]

33. Wang, L.; Zhuo, Z. On the Positional Problem of the Pinus Taiwanensis Forest in the Vegetation Altitude Belts of Mt. Lushan. Chin. J. Plan. Ecol. 1989, 13, 28-35. (In Chinese)

34. Rathgeber, C.B.K.; Rossi, S.; Bontemps, J.D. Cambial activity related to tree size in a mature silver-fir plantation. Ann. Bot. 2011, 108, 429-438. [CrossRef]

35. Jiang, Y.; Zhang, Y.; Guo, Y.; Kang, M.; Wang, M.; Wang, B. Intra-Annual Xylem Growth of Larix principis-rupprechtii at Its Upper and Lower Distribution Limits on the Luyashan Mountain in North-Central China. Forests 2015, 6, 3809-3827. [CrossRef]

36. Delpierre, N.; Lireux, S.; Hartig, F.; Camarero, J.J.; Cheaib, A.; Čufar, K.; Cuny, H.; Deslauriers, A.; Fonti, P.; Gričar, J.; et al. Chilling and forcing temperatures interact to predict the onset of wood formation in Northern Hemisphere conifers. Glob. Chang. Biol. 2019, 25, 1089-1105. [CrossRef]

37. Eilmann, B.; Zweifel, R.; Buchmann, N.; Pannatier, E.G.; Rigling, A. Drought alters timing, quantity, and quality of wood formation in Scots pine. J. Exp. Bot. 2011, 62, 2763-2771. [CrossRef]

38. Gruber, A.; Strobl, A.; Veit, B.; Oberhuber, W. Impact of drought on the temporal dynamics of wood formation in Pinus sylvestris. Tree Physiol. 2010, 30, 490-501. [CrossRef]

39. Chen, D.; Fang, K.; Li, Y.; Dong, Z.; Zhang, Y.; Zhou, F. Response of Pinus taiwanensis growth to climate changes at its southern limit of Daiyun Mountain, mainland China Fujian Province. Sci. China Earth Sci. 2016, 59, 328-336. [CrossRef]

40. Cai, Q.; Liu, Y.; Qian, H.; Liu, R. Inverse effects of recent warming on trees growing at the low and high altitudes of the Dabie Mountains, subtropical China. Dendrochronologia 2019. [CrossRef]

41. Deslauriers, A.; Huang, J.-G.; Balducci, L.; Beaulieu, M.; Rossi, S. The contribution of carbon and water in modulating wood formation in black spruce saplings. Plant Physiol. 2016, 170, 2072-2084. [CrossRef] [PubMed]

42. Hagedorn, F.; Joseph, J.; Peter, M.; Luster, J.; Pritsch, K.; Geppert, U.; Kerner, R.; Molinier, V.; Egli, S.; Schaub, M. Recovery of trees from drought depends on belowground sink control. Nat. Plants 2016, 2, 16111. [CrossRef] [PubMed]

43. Hacket-Pain, A.J.; Ascoli, D.; Vacchiano, G.; Biondi, F.; Cavin, L.; Conedera, M.; Drobyshev, I.; Linan, I.D.; Friend, A.D.; Grabner, M. Climatically controlled reproduction drives interannual growth variability in a temperate tree species. Ecol. Lett. 2018, 21, 1833-1844. [CrossRef] [PubMed]

44. Lauder, J.D.; Moran, E.V.; Hart, S.C. Fight or flight? Potential tradeoffs between drought defense and reproduction in conifers. Tree Physiol. 2019, 39, 1071-1085. [CrossRef]

45. De Luis, M.; Gričar, J.; Čufar, K.; Raventós, J. Seasonal dynamics of wood formation in Pinus halepensis from dry and semi-arid ecosystems in Spain. IAWA J. 2007, 28, 389-404. [CrossRef]

46. Vieira, J.; Campelo, F.; Rossi, S.; Carvalho, A.; Freitas, H.; Nabais, C. Adjustment Capacity of Maritime Pine Cambial Activity in Drought-Prone Environments. PLoS ONE 2015, 10, e0126223. [CrossRef]

47. Fajstavr, M.; Bednářová, E.; Nezval, O.; Giagli, K.; Gryc, V.; Vavrćík, H.; Horáček, P.; Urban, J. How needle phenology indicates the changes of xylem cell formation during drought stress in Pinus sylvestris $\mathrm{L}$. Dendrochronologia 2019, 56, 125600. [CrossRef] 
48. Ren, P.; Ziaco, E.; Rossi, S.; Biondi, F.; Prislan, P.; Liang, E. Growth rate rather than growing season length determines wood biomass in dry environments. Agric. For. Meteorol. 2019, 271, 46-53. [CrossRef]

49. King, G.M.; Gugerli, F.; Fonti, P.; Frank, D.C. Tree growth response along an elevational gradient: Climate or genetics? Oecologia 2013, 173, 1587-1600. [CrossRef]

50. Su, J.; Gou, X.; Deng, Y.; Zhang, R.; Liu, W.; Zhang, F.; Lu, M.; Chen, Y.; Zheng, W. Tree growth response of Fokienia hodginsii to recent climate warming and drought in southwest China. Int. J. Biometeorol. 2017, 61, 2085-2096. [CrossRef]

51. Zhou, G.; Peng, C.; Li, Y.; Liu, S.; Zhang, Q.; Tang, X.; Liu, J.; Yan, J.; Zhang, D.; Chu, G. A climate change-induced threat to the ecological resilience of a subtropical monsoon evergreen broad-leaved forest in Southern China. Glob. Chang. Biol. 2013, 19, 1197-1210. [CrossRef] [PubMed]

C 2019 by the authors. Licensee MDPI, Basel, Switzerland. This article is an open access article distributed under the terms and conditions of the Creative Commons Attribution (CC BY) license (http://creativecommons.org/licenses/by/4.0/). 